\title{
A People's Choice: Persuasive Strategies in the Scottish Independence Referendum
}

\author{
By Carlota M. Moragas-Fernández* \\ Arantxa Capdevila Gómez"
}

On 18 September 2014 Scottish citizens had to decide whether they would like to continue being part of the United Kingdom or not by answering the question: "Should Scotland be an independent country?". Two years before, both the Yes Scotland and the Better Together campaign started to build their discourses about what Independence would imply. The aim of the present study is to analyze which are the different arguments that lay beneath these discourses, paying special attention to the use of figures such as personifications, metonyms and metaphors. For that, we have chosen the main political adverts from both campaigns and we have analyzed them by applying a rhetorical-argumentative methodology. Among the main results, the underlining of the importance of the decision that has to be taken on $18^{\text {th }}$ September by presenting independence as an opportunity to build a fairer and more prosper country or as a risky option must be stressed.

Keywords: independence, political advertising, referendum, rhetoric, Scotland

\section{Introduction}

The 2007 Scottish Parliament election brought the Scottish National Party (SNP) to achieve the greatest number of seats in Holyrood ${ }^{1}$ (47 out of 129 deputies) closely followed by the Scottish Labour Party (46 out of 129 deputies) who had ruled the country since the Parliament was restored in 1999. This change in the political spectrum (the SNP won 20 seats more than the 2004 election) responded to a wide number of factors. One of these factors was related to the SPN ability to focus its manifesto on "emphasising its ability to provide Scotland with effective (devolved) government" (Curtice, McCrone, McEwen, Marsh \& Ormston, 2009, p. 6) rather than on the independence issue. After four years ruling the Scottish Government, Salmond was re-elected as First Minister in May 2011. This time, the SNP manifesto had a clear mandate to let people from Scotland decide their future ${ }^{2}$.

The overall majority achieved by the SNP was the first step in the consecution of an agreement that would allow the holding of a referendum on Scotland's independence. The Edinburgh Agreement, signed on $15^{\text {th }}$ October 2012, between the Scottish Government and the United Kingdom, materialised

\footnotetext{
* PhD Canadidate, Universitat Rovira i Virgili, Spain.

${ }^{\dagger}$ Senior Lecturer, Universitat Rovira i Virgili, Spain.

${ }^{1}$ Holyrood is an informal (but most used) way used to refer to the Scottish Parliament.

2 "We think the people of Scotland should decide our nation's future in a democratic referendum and opinion polls suggest that most Scots agree. We will, therefore, bring forward our Referendum Bill in this next Parliament" (SNP, 2011).
} 
the will of First Minister Alex Salmond to obtain the legislative competence needed to call a referendum before the end of 2014 and to respect the result of ballot boxes whatever it would be. The question to be asked to Scottish citizens finally -after the Electoral Commission recommendations- was: "Should Scotland be an independent country?" and there were only two possible answers (Yes/No) and the date chosen $18^{\text {th }}$ September 2014. The date was announced on $21^{\text {st }}$ March 2013, but both Yes and No campaign had launched nearly a year before. Their goal was to work on persuasive discourses that could be able to call upon and convince their voters and one of the formats they worked with for that purpose was political advertising.

\section{Theoretical Framework}

\section{The Construction of the Persuasive Discourse}

Intellectio, inventio, dispositio, elocutio, memoria and actio are the rhetorical operations in which rhetoric-argumentative analysis is based on. Intellectio, memoria and actio are related to the non-discursive dimension of the speech (the referent) while inventio, dispositio and elocutio refer to the text strictly speaking (Albaladejo, 1991). Hence, Rhetoric not only focuses on the rhetoric text, but also on the links that this text establishes with other elements that influence the communication process (orator, public, referent and context).

Intellectio is the first stage in the construction of the speech. It takes place before the orator starts to think about what has to be said and its main goal is to establish the bases on which the text will evolve (who is the public, through which media are we going to broadcast our message, what do we want to talk about...). Inventio is the phase where the orator looks for the ideas that are going to guide the construction of the persuasive discourse. The semantic macrostructures that sustain discourse on this level are structured in the next rhetorical operation: dispositio. The next stage in the construction of the persuasive discourse, then, needs to be focused on finding the right words, images or sounds that can transmit properly what has been thought before. So, elocutio is the operation where macrostructures are rendered visible through the different resources Rhetoric gives to the orator (figures and tropes). This rhetorical operation wants to catch the attention of the audience through the embellishment of the rhetorical text. However, the career path of the persuasive discourse does not stop here. When discourses have to be spoken in public, the orator must memorize and retain the key ideas of the text and how they are structured to avoid reading his/her discourse. This corresponds to the operation of memoria. Once this phase is over, we get to the most superficial level of rhetorical operations, the actio or pronunciation, which is the staging of the discourse.

The logical and lineal construction of persuasive discourse is done in an opposite way in its analysis. When we look at a persuasive text, we depart form 
the superficial level to discover, in the end, the deepest level of the text. We make our way from actio to intellectio (Capdevila, 2004).

\section{Political Advertising}

Rhetoric as a methodology of discourse construction can be applied to several formats and political advertising is a great example. Teresa Sádaba (2003, p. 165) talks about political ads as "mensajes políticos en campaña, eminentemente persuasivos, construidos por los propios partidos y no mediatizados por los medios de comunicación". ${ }^{1}$ Also Linda L. Kaid and Christina Holtz-Bacha (1995) underline the possibility to control the content of what has to be said and "have an opportunity to affect the outcome or the effect of the message". Since they are no mediated, campaign ads let political parties transmit the message they want and that is why we consider them a proper format to study the persuasive strategies of both Yes Campaign and Better Together Campaign in the Scottish Independence Referendum Campaign. Therefore, the only requirement on television is the adaptation to the audiovisual language.

Television is the main media through which the electorate know not only political parties or their candidates, but in Scotland's Independence Referendum campaign, also the message to call up and convince voters. This is important because, even that the Internet is playing a major role in the dissemination of political information, television "remains dominant as the most highly resourced and far-reaching medium of mass communication" (Gurevitch, Coleman \& Blumler, 2009). What is true, however, is that in the Internet era we can find some political ads that have been thought to go viral and, because of that, are designed following a 2.0 logic (Ridout, Franklin, Fowler \& Branstetter, 2010). Actually, recent definitions of political advertising (Peña Jiménez, 2010) make reference to the different platforms where ads can be shared. This is a trend Lorena Gómez and Arantxa Capdevila (2012) point out when stating that the increasing importance of Internet as a new media has derived in a multiplication of political ads broadcast by each party. Viral videos are an example of the possibilities that the Internet offers to political advertising. The ability to share them through social media and to multiply exponentially its dissemination and the existence of platforms Youtube have also brought formal changes in political advertising. For instance, advertisers have taken advantage of their knowledge in this field and have created political ads that seem to match perfectly the Internet dynamics. If we look at Yes Scotland advertisement "On $18^{\text {th }}$ September \#VoteYes" we see that the hashtag \#VoteYes, which is a device mostly used on Twitter, is not only in the title, but also on screen, even when the advertisement makes the final call to voters.

Anne Johnston and Lynda L. Kaid (2002) underline two main functions of political ads. They say that they help candidates and parties to define their

${ }^{1}$ Political messages broadcasted during campaign periods, especially persuasive, which are built by political parties and are no mediated by media. 
image and that they become a forum where campaign issues can be further discussed. In the case of the Scottish referendum, what has to be constructed is the image of the independent Scotland or the nation as part of the United Kingdom and that is what we are going to analyse in the present study.

\section{Method}

\section{A Rhetorical-Argumentative Methodology}

As mentioned before, our unit of analysis are the political ads made by Yes Scotland and Better Together during the Referendum Campaign. Our goal is to determine which were the strategies and the arguments they used to convince Scottish voters in a way or another. Because of that, we are going to use a rhetorical-argumentative methodology, which is based on Discourse Analysis. We have decided to choose this method because it specially focuses on the persuasive nature of political discourses.

Rhetorical-argumentative analysis distinguishes between three different levels of the speech: deep level, intermediate level and superficial level. These levels are related to the three rhetorical operations that concern the text: inventio, dispositio and elocutio. In this research we are going to pay attention to the deep level and the superficial level. In the first one, we can find the semantic macrostructures included in certain possible worlds (Eco, 1979) that let the orator enclose them. The vision of the reality that political organizations design to persuade voters is fixed in this level. This particular vision is rendered visible in the superficial level, where visual microstructures organize discourse in its formal dimension. In this phase, the orator decides which resources is he going to use to express what he wants to say, which determines the style of the speech (Van Dijk, 1988). Hence, we are going to analyse the text paying attention to the categories of analysis resumed below these lines and that make up inventio and elocutio.

Possible worlds are in charge of delimiting the interpretation of the rhetoric text in the deep level of discourse. At the same time, they work as a frame where inventio is developed and that is why they have to be inhabited by the ideas and arguments that are going to sustain the persuasive discourse. These ideas and arguments are rooted in different elements that belong to reality. They are about "general agreement", which is defined by Chaïm Perelman and Lucie Olbrechts-Tyteca (1989) as the starting point of argumentation. We can distinguish between two categories of agreement: the first one relates to facts, truths and presumptions, which are the most accepted among audience, while the second one deals with values, hierarchies and loci of the preferable, which have a more limited character due to its more subjective component.

In order to make possible worlds plausible we need to use argument techniques that will let discourse achieve the transmission of validity between the starting point agreed by the orator and the audience and the new 
conclusions that have still to be agreed by both participants in the communicative act. In this context we can find quasi-logical arguments, whose principal objective is to provoke changes in audience's thought to get their acceptance. As Perelman and Olbrechts-Tyteca (1989) state, there are two different kinds of arguments: liaison and dissociation arguments. The first ones include quasi-logical arguments (logical structures and mathematic relations), appeals to reality (succession and coexistence) and arguments to establish the real (example, illustration and model). On the other hand, dissociation arguments intend to separate elements that are considered to belong to the same system of thought. They bring us to relate two concepts of our culture that form what we know as philosophical binomial.

All ideas and arguments that have been generated in the previous phase have to be transmitted to the audience through written or audiovisual language in the superficial level. We are going to identify them by focusing on the figures of the speech, which are, following Stefano Arduini (2000) the medium that let us organize the world and refer it. Arduini groups these rhetorical devices in six figurative fields: metaphor, metonym, synecdoche, antithesis, repetition and ellipsis. Metaphor is "the application of an alien name by transference" as defined by Aristotle in The Poetics (1995). As a tool that let us give a new meaning to a word, which is completely different than what it literally means, it can evoke emotional responses (Charteris-Black, 2011), so it is a great device to persuade the audience. Metonym is also a transfer of meaning but it is based on a relation of contiguity among elements that replace the part for the whole. Therefore, the difference between metaphor and metonym belongs to the different relation they establish between the natural term and the figurative one (by analogy or by contiguity). Synecdoche is the opposite operation of metonym, which means that it is the replacement of the whole for a part that represents it. Regarding antithesis, this rhetoric device involves a contradiction of ideas and can be easy identified in the superficial level because the orator frequently uses it to represent a dissociation argument that has been used in the deep level. Finally, we can find repetition and ellipsis. Repetition is based on the reproduction of formal or conceptual structures, whereas ellipsis deals with the omission of words or images in the space of something that has not been said or seen.

\section{Results}

\section{Yes Scotland: An Opportunity to Choose Scottish People's Future}

Yes Scotland campaign was represented in audiovisual terms by two political ads: "A choice between two futures"1 and "On $18^{\text {th }}$ September

\footnotetext{
1 "A choice between two futures" Retrieved from http://bit.ly/1lp8MW2. [Accessed: 6 April 2015]
} 
\#VoteYes"1. In the first one, we can see a girl, Kirsty, who is born on 18 September 2014, the same date of the referendum. She starts making lots of questions contrasting her future in an independent Scotland and her future in a Scotland that is governed by Westminster. The audience is expected to answer all these questions by voting Yes, cause it is presented as the best option for Kirsty's future. It is the best option for common people, who only want to live in a better country. So, the decision is presented as "a choice based on who you trust to make Scotland the better country to live in: the politicians of Westminster or people who live here in Scotland". The other advertisement, "On $18^{\text {th }}$ September \#VoteYes", also reinforces the civic and participative character of Yes Scotland movement and, consequently, of a Yes vote and an independent Scotland. In order to do it, the advertisement gathers 32 high profile celebrities who support independence that reinforce the arguments in which Yes campaign is sustained.

\section{Figure 1. Yes Scotland Campaign's Argumentative Strategy}

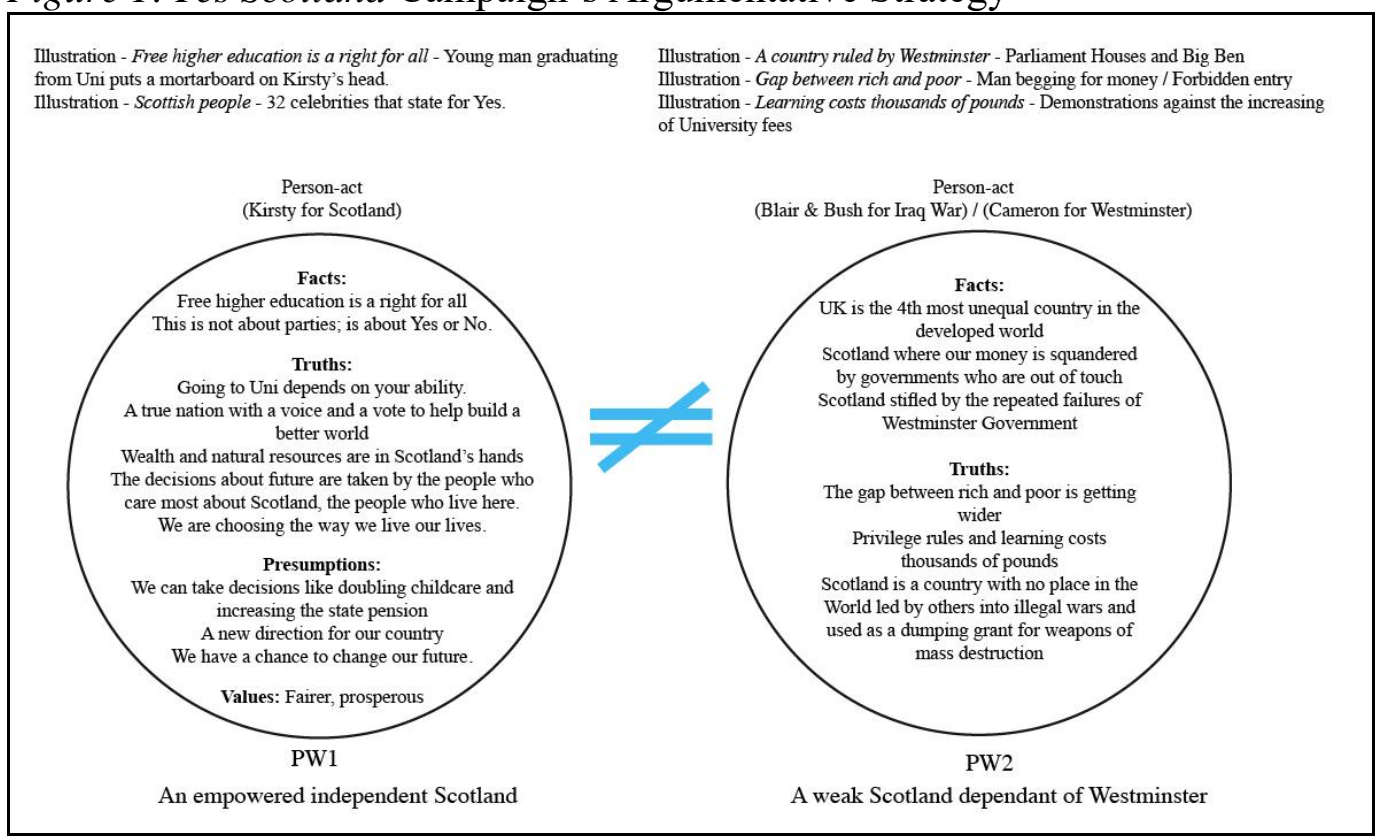

In the deep level, discourse is structured in two possible worlds that are constructed in an opposite way, as depicted in Figure 1. We can identify, then, a philosophical binomial between them. The macrostructure that sustains Possible World 1 is "An empowered independent Scotland". It is presented as a world owned by the people who live in Scotland where future will be better. This world is inhabited by values like fairness, pride, enthusiasm, bravery and prosperity and sustains this "better Scotland" through facts, truths and presumptions. A better Scotland has to be rooted on a bet for the welfare state and against the cuts promoted by the Westminster government. A fact that reinforces this idea is that "free higher education has to be a right for all",

1 "On $18^{\text {th }}$ September \#VoteYes" Retrieved from http://bit.ly/1FE0GNY. [Accessed: 6 April 2015] 
which is complemented by truths like "a Scotland where going to the United Kingdom depends on your ability" and "where our wealth and natural resources are in Scotland's hands". The Scotland presented in this PW is also an empowered Scotland that has come of age and has the right to decide its future. As a country that belongs to what Montserrat Guibernau (2013) denominates "emancipatory nationalism movements", Scotland's way from adolescence to adulthood is "illustrated by the nation's willingness to act and be recognized as a 'demos' able to decide upon its own political future" (p. 372). This discourse is set out using truths "the decisions are taken by the people who care most about Scotland" and presumptions "we can take decisions like doubling childcare and increasing the state pension". The journey from birth to adulthood is embodied by Kirsty, who is related to Scotland through a relation of coexistence (analogy) that associates her life to the country's life. This itinerary is also supported by an illustration that shows a young man graduating from the United Kingdom that puts a mortarboard on Kirsty's head to symbolize a Scotland where everybody can accede to higher education. The whole arguments displayed in PW1 are reinforced by facts, truths and presumptions of the people who live in Scotland. As well as the institutional discourse, there are some facts that stress the identification of Independence as people's option: "This is about who is gonna be in the governance in your country", "It is about us, because we want this place to be different" or "This is not about parties". Also truths like "We are choosing the way we live our lives" and "Scottish people will get the government they choose" or presumptions like "We have a chance to change our future" are stated in these sense.

In contrast, Possible World 2 is ruled by the politicians of Westminster and people from Scotland have no choice to decide their future. A series of facts and truths develop the macrostructure that sustains Possible World 2: "A weak Scotland dependant of Westminster". For instance, facts like "UK is the $4^{\text {th }}$ most unequal country in the developed world" or "Our money is squandered by governments who are out of touch" are used to indicate that the kind of Scotland people will live in if voting No would be far from being fairer or empowered. Who would like to live in a "Scotland with no place in the World" where "the gap between rich and poor is getting wider and learning costs thousands of pounds"? These truths inhabit "A weak Scotland dependant of Westminster" and are unavoidably compared with the facts and truths that belong to "An empowered independent Scotland". As a part of this opposition we can identify also three different illustrations whose aim is to strengthen the strategy that presents PW2 as unfair and insensitive to welfare policies. The first one portrays a "country ruled by Westminster" with symbolic places like the Parliament Houses and Big Ben, the second one illustrates the "gap between rich and poor getting wider" with a man begging for money and a forbidden entry sign while the third one shows student demonstrations against the increasing of University fees to denounce that "Learning costs thousands of pounds". In addition to that, there are also two person-act arguments that insist on the idea of presenting Scotland inside the United Kingdom as a place where 
important decisions are in the hands of politicians that work thousands of miles away and do not look at what is better for Scotland.

Figure 2. "The Future in an Independent Scotland" and "The Future With Westminster"
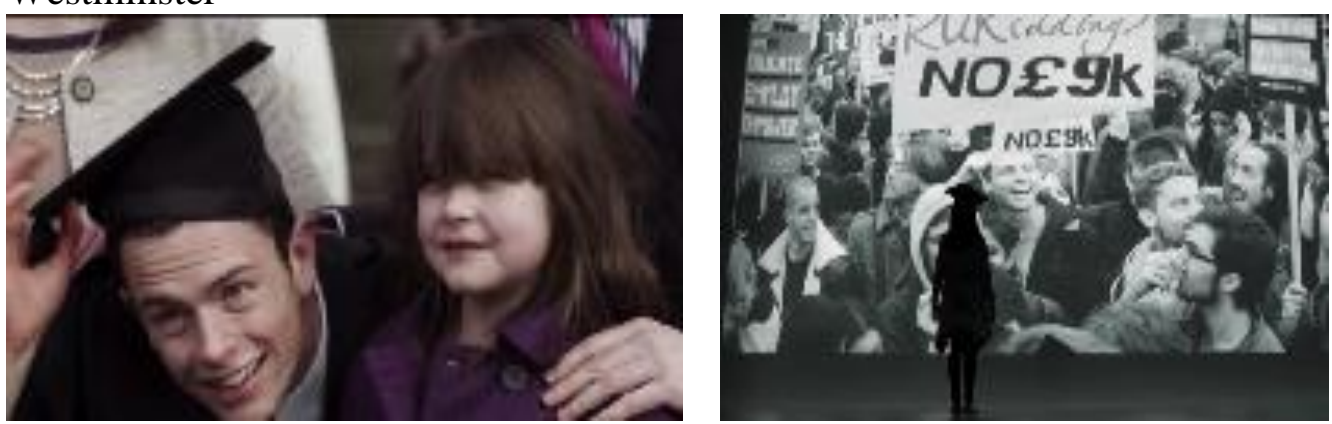

The philosophical binomial we detect in the deep level turns into an antithesis in the superficial level (Figure 2). The coloured images that belong to "An empowered independent Scotland" contrast with the black and white pictures used to show "A weak Scotland dependant of Westminster". There is also a metaphor that presents Kirsty as Scotland. Scotland is a child and, because of that, it has a whole life to live. It has to grow up, to experiment and to learn how to be an independent country and that is part of the way. Scotland is departing from the place where it is now (inside the UK and anchored in the ostracism of Westminster) to its new future on $18^{\text {th }}$ September 2014. Hence, we detect another metaphor: the independence process of Scotland is a journey. And this journey is presented by stating that "we choose a new direction for our country" as we see Kirsty riding a bicycle in a path. The persuasiveness of these two metaphors lays on the association of a kid's thrill for what is new to the excitement that taking a new way that will allow Scottish people to improve their lives. Furthermore, we can find metonyms such as Tony Blair and George Bush representing the Iraq war or David Cameron for Westminster Government as well as the 32 participants in the Yes Scotland campaign as part of the Scottish society for Yes. The ad they star in, "On the $18^{\text {th }}$ September \#VoteYes", shows us repetition (Figure 3) as a rhetorical device that is used both in the structure of the spoken discourse and in the advertisement edition. 
Figure 3. "On the $18^{\text {th }}$ September \#VoteYes"

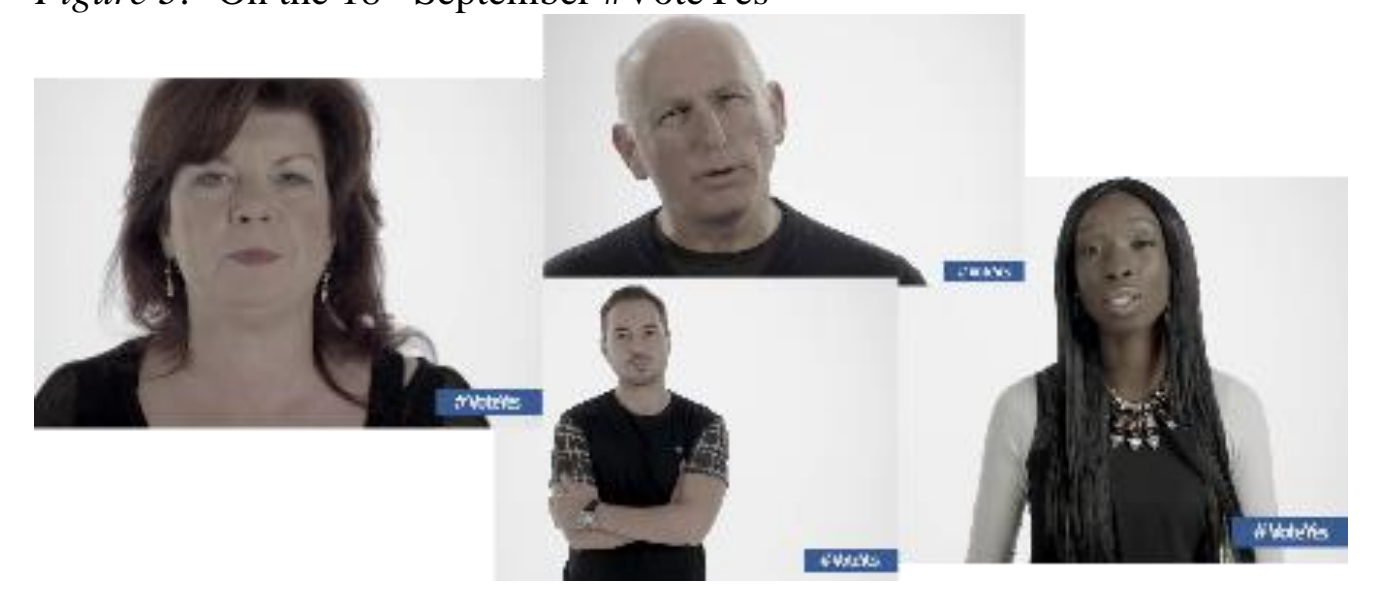

Better Together: Not to Loose What We Have Built Together

There are two advertisements that stand out in the Better Together campaign. The first one is entitled "A proud nation"1 and emphasizes the relation Scotland has established with the UK over three hundred years. It also points out that Labour politicians that have ruled the restored Scottish Parliament have always worked for building a democratic Scotland "as a part of a changing UK" and that the allegiance with the United Kingdom will ensure important things like keeping the pound and defence forces. Gordon Brown, as Scottish and ex Prime Minister of Westminster Government, is the perfect candidate to expound the benefits of the cooperation between Scotland and the United Kingdom. The other political ad that integrates the Better Together campaign is "The woman who made up her mind" ${ }^{2}$ It presents a working mother from Scotland talking in her kitchen about the referendum and considering the threats of being independent to conclude that what is best for her children and for Scotland is to vote No.

Unlike Yes Scotland, Better Together campaign presents two worlds that apparently are not related one another whereas they are both focused on the argumentation of the No vote. This means there is no dissociation or association argument between them. Nevertheless, we can consider that they are somehow connected since they are both designed to answer to a causeeffect relation, which responds to the idea that voting yes implies some of the scenarios the two worlds depict.

\footnotetext{
1 "A proud nation" Retrieved from http://bit.ly/1FE0Fte. [Accessed: 6 April 2015]

2 "The woman who made up her mind" Retrieved from http://bit.ly/1vLXpbs. [Accessed: 6 April 2015]
} 
Figure 4. Better Together Campaign's Argumentative Strategy

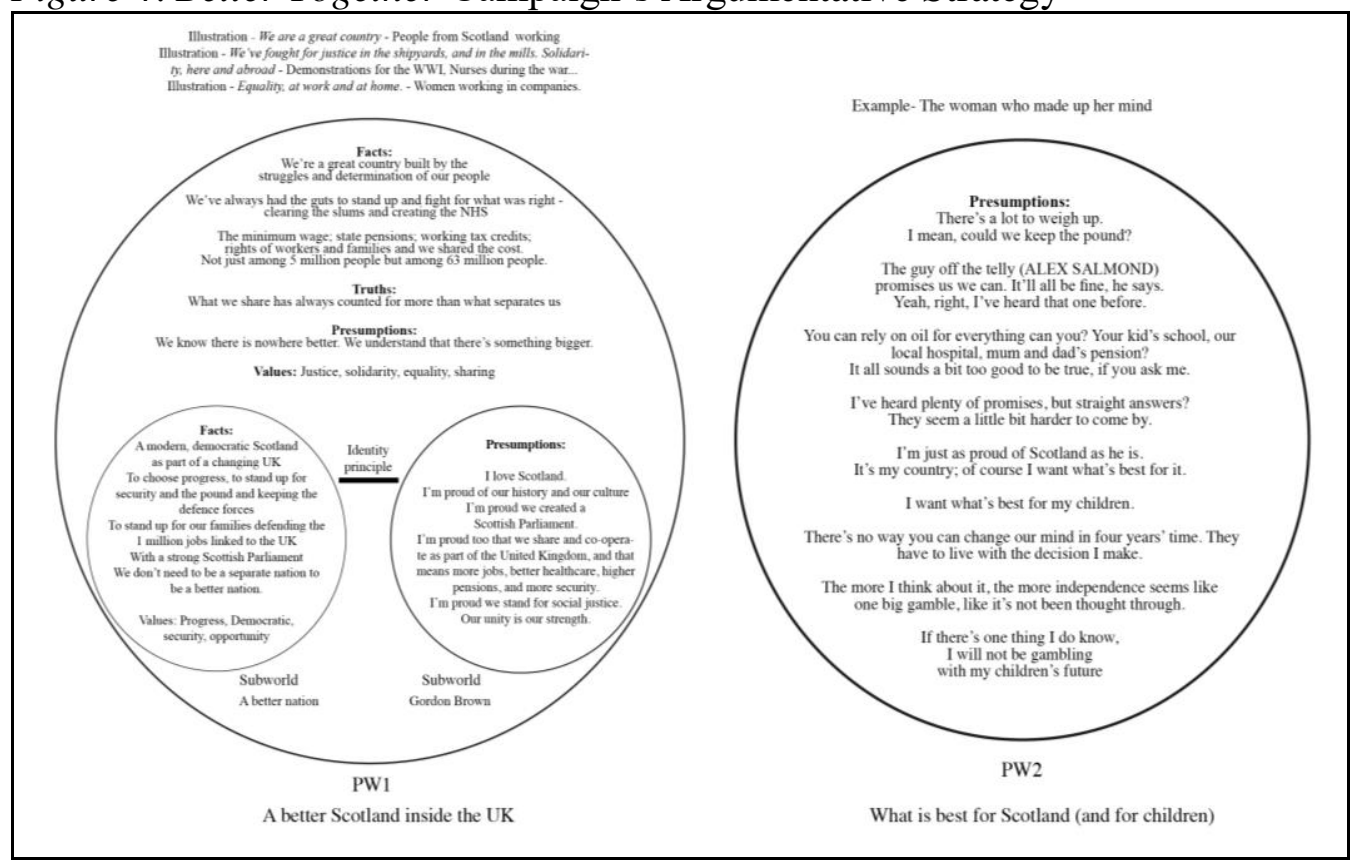

As it is shown in Figure 4, the first Possible World defines the present of Scotland inside the UK, which presents the country as being better as it is nowadays, since it has all the virtues of the Scottish nation plus the strength of the United Kingdom. The second Possible World is developed by the macrostructure "What is best for Scotland (and for children)" and its main objective is to promote the discourse of fear to Independence by appealing to Scotland's future, which is the children's future. So, the campaign focuses on two discourses that share different arguments to persuade the electorate.

Possible World 1 is inhabited by a series of facts, truths and presumptions that confirm that Scotland is better as part of the UK. Statements like "We've always had the guts to stand up and fight for what was right - creating the NHS" or "The minimum wage, state pensions, working tax credits, rights of workers and families and we shared the cost. Not just among 5 million people but among 63 million people" want to make clear that most of the achievements in welfare policies have been reached together. And they have been possible because of the solidarity between the four nations that form the United Kingdom. The idea that staying together is the best option is reinforced with truths like "What we share has always counted for more than what separates us" and presumptions like: "We know there is nowhere better. We understand that there's something bigger." Justice, solidarity or equality are some of the values associated to the Scotland that shares its daily life with the United Kingdom. Inside PW1 we can find two subworlds that live together with it. They develop the macrostructures "A better nation" and "Gordon Brown's nation" that are associated through an identity principle, a quasilogical argument that implies all that we say about the first world can be said about the second. Therefore, both worlds are inhabited by facts and presumptions that underline the pride of being Scottish and having a 
Parliament that has legislative competences but also the opportunities that offers staying inside the UK: "more jobs, better healthcare, higher pensions, and more security".

The structure of Possible World 2 is quite simple. It develops the macrostructure "What is best for Scotland (and for children)" and does it with a series of presumptions. Among these presumptions, we can find some that refer to the problems of making such an important decision: "There's not much time left for me to make a decision. They (children) have to live with the decision I make". This fear of taking the wrong decision is motivated by the uncertainties associated to a hypothetical independent Scotland: "Could we keep the pound?" There are more arguments that make the woman who appears in the advertisement question the viability of an independent country. For instance, she states she has only heard promises, but not straight answers and that makes independence look like a "big gamble". She won't be gambling with her children's future, so, in the end, she makes up her mind and decides to vote no. What is important about this discourse is that it uses an argument that establishes the real (an example) to support an argumentation destined to persuade Scottish woman, who was one of the most undecided groups in the referendum campaign.

Figure 5. "A Proud Nation"
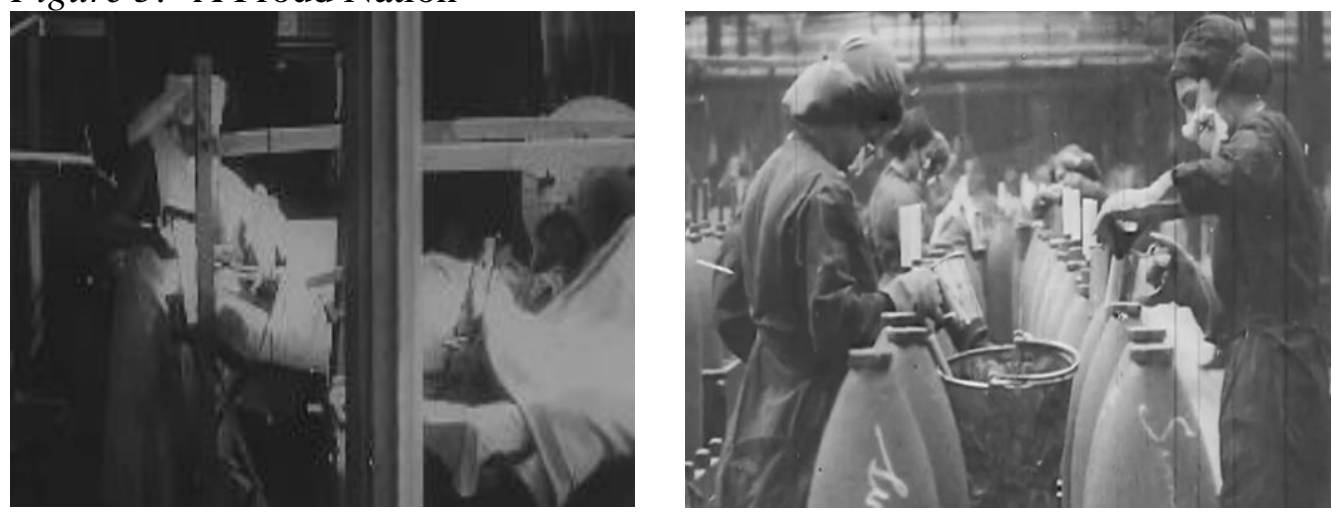

This example, precisely, turns into a metonym because it visually presents a Working mother as a part of the whole target of the advertisement. Other metonyms that should be outlined are the ones used to reinforce the spoken discourse like pictures of the demonstrations for the WWI or nurses working during a conflict for all people from the UK, Scottish citizens included. Also the metonym that portrays some women working to symbolize all UK women who achieved "equality, at work and at home" (Figure 5). These are relevant goals that Scotland has achieved together with the UK and remembering them to the audience responds to a strategy of legitimization of the Union. We only can find another rhetorical device in the superficial level of Better Together's argumentative strategy. This is the Journey metaphor, which also appeared in Yes Scotland campaign. While is not developed in the pictures that illustrate "A proud nation" we can identify statements like: "Donald Dewar started building a modern, democratic Scotland as part of a changing UK. And that journey, 
continuous." Scotland recovered its Parliament on 1997. This is presented as the starting point on Scotland's recovery of a certain grade of autonomy without being outside the UK. As said in the advertisement, the journey that started then should continue now. Despite we identify the same conceptual domain in Yes Scotland campaign, the narrative under which this domain is displayed are different cause they present two different scenarios (Musolff, 2004).

\section{Conclusions}

In a moment where the political class is constantly loosing popularity the strategy of Yes Scotland was an appropriated one. To associate Yes vote to people's vote and to unlink all what reminded to old-politics from the hypothetical independent Scotland was a good decision. However, the only thing Yes Scotland could use to talk about an independent Scotland was enthusiasm and the country's wish to get more powers and become a state within full rights in order to take its own decisions without depending on Westminster. So the arguments for voting Yes lacked of a visual support that could make them more comprehensible for the electorate. Actually, only free higher education was portrayed in Yes Scotland campaign. All the other promises were always presented with images of Kirsty growing up or the 32 celebrities participating in the ad "On the $18^{\text {th }}$ September \#VoteYes", cause they cannot be materialised for now. On the other hand, "The future with Westminster" was well illustrated with pictures that underline every single argument about its bad management. Better Together campaign opted for showing what the Union meant to them and to Scottish people that were proud of being part of UK. And that seemed to be a well-focused discourse, because it also underlined the important role the Scottish Parliament had been playing since devolution. However, when the campaign was ending, the No discourse went tougher and outlined what an independent Scotland would loose instead of what would gain if it stayed with the United Kingdom. What must be stressed in both campaigns is the appealing to children's future in order to influence people's vote in a direction or another and the delegation of the responsibility in the result, whatever it was, and, consequently, Scotland's future in citizens vote.

\section{Acknowledgments}

This research was supported by the Spanish Ministry of Economy through the project "The Metaphor Role in the Definition and Social Perception of Conflict Issues: Institutions, Media, and Citizens" [CSO2013-41661-P]. 


\section{References}

Albaladejo, T. (1991). La Retórica [Rhetoric]. Madrid: Síntesis.

Arduini, S. (2000). Prolegómenos a Una Teoría General de las Figuras [Introduction to a General Theory of Figures]. Murcia: Universidad de Murcia.

Aristotle. (1995). The Poetics. Cambridge (Mass.): Harvard University Press.

Capdevila, A. (2004). El Discurso Persuasivo. La Estructura Retórica de los Espots Electorales [Persuasive Discourse. The Rhetorical Structure of Political Advertisements]. Zaragoza: Aldea Global.

Charteris-Black, J. (2011). Politicians and Rhetoric. The Persuasive Power of Metaphor. United Kingdom: Palgrave Macmillan.

Curtice, J., McCrone, D., McEwen, N., Marsh, M. and Ormston, R. (2009). Revolution or Evolution? The 2007 Scottish Elections. Edinburgh: Edinburgh University Press.

Eco, U. (1979). The Role of the Reader: Explorations in the Semiotics of Texts. Bloomington: Indiana University Press.

Gómez, L. and Capdevila, A. (2012). Variaciones estratégicas en los spots electorales de televisión y de Internet en la campaña electoral [Strategic variations in political advertisements on Television and on the Internet during electoral campaigns]. ZER, 17(33), p. 67-86.

Guibernau, M. (2013). Secessionism in Catalonia: After democracy. Ethnopolitics, 12(4), p. 368-393.

Gurevitch, M., Coleman, S. and Blumler, J. (2009). Political communication - Old and new media relationships. The ANNALS of the American Academy of Political and Social Science, 625(164).

Johnston, A. and Kaid, L. (2002). Image ads and issue ads in U.S. presidential advertising: Using videostyle to explore stylistic differences in televised political ads from 1952 to 2000. Journal of Communication, 52(2), p. 281-300.

Kaid, L. and Holtz-Bacha, C. (1995). Political Advertising in Western Democracies: Parties \& Candidates on Television. Thousand Oaks, California: SAGE Publications.

Musolff, A. (2004). Metaphor and Political Discourse. Analogical Reasoning in Debates about Europe. United Kingdom: Palgrave Macmillan.

Peña Jiménez, P. (2010). El spot electoral: La retórica del audiovisual [Political advertisements: The rhetoric of the audiovisual]. In Comunicación y Desarrollo en la Era Digital. II Congreso de la AE-IC. February 3-5, Málaga.

Perelman, C. and Olbrechts-Tyteca, L. (1989). Tratado de la Argumentación: La Nueva Retórica [The New Rhetoric: A Treatise on Argumentation]. Madrid: Gredos.

Ridout, T., Franklin Fowler, E. and Branstetter, J. (2010). Political Advertising in the $21^{\text {st }}$ Century: The Rise of the YouTube Ad. In. The Annual Meeting of the American Political Science Association. September 2-5, Washington, D.C.

Sádaba, T. (2003). Los anuncios de los partidos en televisión. El caso de España (1993-2000) [Political advertisements on Televison: The case of Spain (19932000)] In. Berrocal, S. (ed.) Comunicación Política en Televisión y Nuevos Medios [Political Communication on Television and New Media]. Barcelona: Ariel.

SNP-Scottish National Party. (2011). Scottish National Party Manifesto 2011. Retrieved from http://bit.ly/1qECRln. [Accessed: 27 March 2015]

Van Dijk, T. (1988). News as Discourse. New Jersey: Lawrence Erlbaum Associates Inc. Publishers. 
